\title{
Szerbhoruáth György
}

\section{Jöhet a csevap}

\section{Zárójelben a „hı a - vajdaságı - magyar??-hoz}

Hadd kezdjem én is a hollandokkal, ha már szóba került Hadas Miklós írásában, ki hol, hogyan vált jegyet a tömegközlekedésben. Úgy hat éve egy Hollandiában élő vajdasági magyar (származású) barátnőm megkért, hogy míg holland férjével (aki félig fríz) a horvát tengerparton nyaralnak („megyünk egy kicsit haza”, mondta Ildi, noha már szülei és testvérei sem éltek ekkor a volt Jugoszláviában vagy két évtizede), addig vigyázzak a házukra, mely egy Amszterdam melletti gazdagabb alvóvárosban van. „Tudod - mondta -, mostanában sok a betörés, ezek a balkániak..” Mire figyelmeztettem Ildit, hogy én is és ő is, azaz mi, a Balkánról érkeztünk. Szerbiából, az meg ott van, hiába, hogy a Vajdaság a Száva-Duna vonalától északra fekszik, s ez lenne a határ. Amikor pedig megérkeztem, ideadta a bérletét is, nehogy már jegyre költsek amszterdami bolyongásaim során. Emlékszem, amikor Ildi 1992-ben kikerült, büszkén írta, sosem vesz jegyet, és hiába kapják el, nincs személyije, vagyis azt senki sem kérheti el, ha jól emlékszem a sztorira. Lám, a vér nem válik vízzé, mi strukturálisan arra vagyunk kondicionálva, hogy blicceljünk. Ám miért rettegek én az ellenőröktől akkor is, ha érvényes jegyem, bérletem van?

Talán azért, mert Jugoszláviában/Szerbiában szocializálódva ösztönösen, de sokszor jogosan is, mindig féltem a hatalom embereitől. Hisz kisebbségi vagyok, más az anyanyelvem, mint a többségé, folyamatosan illeszkednem kell, tartani valamitől, ami nem vagyok, az ismeretlentől, amit úgysem ismerhetek meg. Úgyis más vagyok, más maradok. Magyarországra áttelepülten is. Megtanultam bliccelni is, amire a Vajdaságban, falusi lévén, lehetőség nem akadt, legfeljebb a vonaton, de azon egyébként is a kalauz lefizetése dívott. Csínján hát a következtetésekkel a habitusról: nehéz úgy jegy nélkül utazni, ha nincs min utazni.

„A magyarok a Vajdaságban: a másságok mássága. Ebben az értelemben, az eleve csekély nagyságrend, valamint a folytonos zsugorodás ellenére, intellektuálisan mindig izgalmasak maradunk; érdemes rólunk, többrétegű identitásunkról gondolkodni, még ha ténylegesen 
hallgatnak is rólunk, szinte mindenütt” - írta Losoncz Alpár a Ki vagy te, vajdasági magyar? kérdésére 2017-ben (2017: 85). A hasoncímü kötet Újvidéken jelent meg. Tizenöt vajdasági magyar kötődésű szerző válaszolt a szerkesztő, Losoncz Márk kérdésére, melyet megfogalmazni sem volt könnyü. Mert noha az inspirációt a „Mi a magyar?” kérdése adta, e kérdés így, e formában - ha nem is elcsépelt - mégis elkanyarodik e helyi identitás lényegi problémáitól, vagyis azoktól a problémáktól, amelyek ma egy vajdasági magyart foglalkoztathatnak, nota bene kínozhatnak.

Ha a „Mi a magyar?”-t Hadas Miklós hetvennyolc év után töltötte újra, úgy a vajdasági magyar kérdést is időnként újra át kell futtatni. Éppen száz éve lesz, hogy felmerült e kérdés: először is, hogy mi az a vajdasági, és ha van olyan, hogy vajdasági, akkor mi/ki az a vajdasági magyar? Természetesen az ottani írók tették fel először e kérdést a húszas évek végén, molyoltak rajta rendesen, bár terminológiájuk nem akadt rá. A hatvanas években pedig még az is felmerült, hogy a vajdasági magyar önálló nemzetté válik. Ha már Magyarország elfordult a magyar kisebbségektől, Jugoszláviában pedig már oly jó a kisebbségeknek, hogy elöször is nemzetiségekké váltak (tehát nincs semmi kis, semmi kicsinyesség, alul levés, elnyomás, lecsúszás, lemaradás), s innen már csak egy újabb ugrás a nemzetté válás (ha már ment ez a macedónoknak és a bosnyákoknak a titói Jugoszláviában). A horvát tavasz, a muzulmán ébredés, a szerb liberálisok - és e mozgalmak alkonya, leverése - azonban hamar kijózanítólag hatott a vajdmagy írókra, értelmiségiekre, és a pártelit sem támogatta az effajta újabb nemzetesítést.

Jugoszlávia megszűnt, jöttek a délszláv háborúk, a vajdasági magyarok tízezrével menekültek el, ma pedig gazdasági okok miatt zajlik az exodus. Míg 1991-ben 340 ezer magyart számoltak össze Szerbiában, ma életvitelszerüen ha 180 ezren élnek ott. A pártelit azonban optimista, az egyedüli helyi napilap, a Magyar Szó főszerkesztője a 2018. áprilisi magyarországi választások előtt a következő „kérdést” tette fel a legerősebb ottani párt, a Vajdasági Magyar Szövetség elnökének, Pásztor Istvánnak: „A magyar kormány segítőkészségének köszönhető, hogy kimondottan jó magyarnak lenni Vajdaságban.”

Tehát: jó lenni. Jó magyarnak lenni. A Vajdaságban. Tudjuk, kinek köszönhetően. Még véletlenül sem magunknak.

Kérdés tehát nincs, állítás van, s jól levés, jólét van. Az előbb említett kötet szerzői azonban korántsem fogalmaznak ilyen sommásan. Hiszen a tizenöt szerzőből eleve csupán négy az, aki vajdasági magyar származású és ma ott is él. A többiek vagy Magyarországon élnek, vagy kétlakiak, jönnek-mennek, vagy vegyes házasságból származnak, vagy Belgrádban élnek (ami nem a Vajdaság), és különben is: mi az, hogy magyar, mi az, hogy vajdasági?

Müfajilag is igen vegyesek a válaszok, még novellaféle is akad. Teljes hát a szétfejlödés, mert a kötet jellege, szerkezete rámutat arra, hogy ha a vajdasági magyarság és értelmisége nem is különösebben különleges és figyelemre méltó, mégis „látszik rajta” a balkáni, a keletközép-európai kisebbségek nyomorúsága, összes bája, hibája, öröme és bánata, szerkezetei és strukturálatlansága.

A kötet megjelenését egyébként nem követte zajos siker, nem robbant ki vita, nem, semmi. Legfeljebb a háttérben ment a szokásos vajdmagy truttyogás: hogy miért nem kapott felkérőt ez vagy az a szerző, miért oly sok az olyan válaszadó, aki már rég emigrált, és különben is, ez egy liberális társaság. Hatvan éven felüliből is csak kettő akad, azok sem élnek ott, vagy kétlakiak, pestiek. Csak egy pap akad köztük, ő is költő, s - mint számomra is most derült ki valójában cigány, itt vallja meg elöször, hogy az. Hol vannak a konzervatívok, az igazi ma- 
gyarok? És miért a kérdésben a vajdasági jelző? Miért nem délvidéki magyar? Hisz „sokan” annak vallják magukat. És aki délvidékinek mondja magát, az ugye történelemben gondolkodik, távlatokban, nem a pőre közigazgatási vajdasági jelenben, ergo, illetve eo ipso és de facto magyarabb, mint a vajdasági magyar, mert a vajdasági, az valami szupranacionális akar lenni, mint Jugoszlávia, nemzet a nemzetek fölött, multikulti, ilyképp nemzetellenes, tehát magyarellenes, de legalábbis anacionális, nemzetileg botfülü.

Nem a kérdésre - „Mi a magyar?” - vagy a válaszra való reagálást akarom megkerülni, s ráadásul azt sem hiszem, hogy a vajdasági magyarság, a közösség identitása, identitásformái oly különlegesek lennének, annyira mások, mint az erdélyi, felvidéki, zalai, békési stb. De arra az utóbbi idők kutatásai is világosan rámutatnak, hogy - szétfejlődés vagy sem, nemzetegyesítés vagy sem - e kisebbség regionális tudata egyre markánsabb. Persze, ha azt akarjuk mérni, úgy kérdezünk, az is lesz. Ha felkínáljuk valakinek, hogy etnikai identitását ne pusztán például mint magyart határozza meg, hanem a válaszlehetőségek közt ott a vajdasági magyar is, hát biztos akadnak, akik inkább e cédula után nyúlnak elsőként. Az, hogy magyar, a többség számára úgyis természetes, velünk született dolog, nem pedig isteni kiválasztottság eredménye - ezt is bizonyítják a felmérések.

Így a 2007-es Kárpát Panel vizsgálatban ${ }^{1}$ az ottani fiatal válaszadók, a 15-29 évesek 49 százaléka ama kérdésre, hogy „Leginkább úgy határoznám meg magam, mint...”, első választásként a vajdasági magyart jelölte meg, 24 százalékuk a vajdaságit, a magyart pedig csak („csak”) 16 százalékuk. Másodsorban már a magyarok „győztek” 32 százalékkal, ezt követte a vajdasági magyar 23, majd a vajdasági 20 százalékkal, de itt elöretört a magukat magyar nyelvü szerb állampolgároknak vallók aránya 12 százalékkal. A számok önmagukért beszélnek. Ahogyan az is, hogy az összes magyar régióra kiterjedő kutatás vajdasági vezetője, Gábrity Molnár Irén már tanulmánya címében is délvidéki identitástudatról szól, s másutt is délvidékezik. Miközben a válaszadók közül senki sem vallja magát délvidéki magyarnak (bár meglehet, ez nem szerepelt a feltüntetett válaszok közt, a módszertant pedig nem ismerteti a szerző). Egyébként a többi régió (Kárpátalja, Belső-Erdély, Székelyföld) esetében hasonló eredmények születtek, kivéve Felvidéket.

De emlékszem a kutatással kapcsolatosan egy bizarr esetre. Sajtótájékoztatót tartottak az eredményeket ismertetendő, melyen Gábrity Molnár elmondta, milyen furcsa, hogy a vajdasági válaszadók háromnegyedét szégyennel tölti el, hogy magyarnak született. És hogy ez világviszonylatban is feltűnő - ez a nagymértékü önutálat, amit kutatni kellene. És tényleg, nagyon feltűnő. De még feltűnőbben látszódott, hogy erre aztán mégsem reagált senki: a vajdasági magyarok közül négyből három szégyelli magyarságát. Hát igen, a titói éra, a jugoszláv jólét, a kisebbségi sors mind megtette a hatását... Aztán megnéztem magát a táblázatot, és nem kellett sasszem hozzá, hogy kiszúrjam: az elemző egyszerüen fordítva olvasta le az adatsort, a táblázatot fordítva tartotta. Mert a válaszadók 76 százaléka éppen azt válaszolta, egyáltalán nem ért egyet azzal a kijelentéssel, miszerint az, hogy magyarnak született, szégyennel töltené el... Persze, aki dolgozik, hibázik. Ám szimptomatikus, hogy Gábrity Molnár bejelentése mégsem hökkentette meg annyira a közvéleményt, a hallgatókat, hisz arra senki sem reagált (e sorok íróját leszámítva; ezután korrigálták is a hibát). Mintha voltaképpen - ha jobban belegondolunk - bele is férne a pikszisbe a vajdasági magyarok önutálata, az megérthetö lenne.

1 Ennek vajdasági eredményeiről lásd Gábrity Molnár és T. Mirnics (2002); Gábrity Molnár (2008). 
A lényeg azonban inkább a regionális kötődés erőssége - további adatokkal senkit sem untatnék, de az ottani magyar fiatalok többsége a Vajdaságot tartja a szülöföldjének, de a hazájának is, azzal, hogy mintegy negyedük Szerbiát tartotta annak 2007-ben. Más kutatások is hasonlóan kemény eredményeket hoztak ki (lásd Badis 2008). Azt is kimutatta több kutatás, hogy a határon túliak többsége akár egyszerre tartja magát a magyar nemzet és a többségi, esetünkben a szerb nemzet részének, a politikai és kulturális nemzetkoncepció tehát sokaknál nem üti egymást.

A többes (avagy minimum kettős) identitásról régóta beszélünk már. A nemzeti közömbösségröl is, bár aligha eleget (lásd Zahra 2017 [2010]). Mert nem feltétlenül kelünk s fekszünk azzal, hogy mi a magyar, hogy én mennyire vagyok magyar. Én is csak akkor vagyok magyar, ha kérdezik. Ha nem kérdezik, mindegy, nem gondolok rá. Vajdasági pedig leginkább akkor vagyok, ha a Vajdaságon kívül kell elmagyarázni, honnan származom. A Vajdaságban a többes identitás már csak a vegyes házasságok és az erős asszimilációs kényszerek, vagy éppen az önkéntes asszimiláció miatt is bevett, elismert, nem problematikus, gyakran magától értetődő dolog. Sőt: az a gyanús, ha valaki azt mondja: én száz százalékban ez és ez vagyok. Fél perc alatt kimutatható, már csak a vezetéknév vagy a felmenők vezetéknevei alapján, hogy senki sem tiszta, mindenki vegyes (mondjuk, ez más magyarok, nációk esetében is többnyire így van). A vajdasági magyarok egyharmada sosem élt tömbben, azaz túlnyomóan magyar többségü vidéken, színtiszta magyar településekből sem sok akadt (azok meg jellemzően kisebb, eldugottabb, így elmaradottabb falvak voltak inkább). Legfeljebb ezeket a magyar közösségeket tekinthetjük tehát igazán magyarnak, valami ősmagyarnak, ahol megfigyelhető lenne a speciális magyar habitus, a társadalmi gyakorlatok. Mindenütt másutt ott a német, a zsidó, a szerb hatás. A kapitalizmust, avagy a protestantizmus szellemét azonban a magyarok kevésbé tanulták meg a vállalkozó szellemübb nációk tagjaitól. Ahogy mesélték, a II. világháború előtt a magyar napszámos (mert a javuk föld nélküli volt) legszívesebben a svábnak dolgozott, mert ott akár a dupláját is megkereste, mint a magyar földesúrnál, aki elkártyázta, elkurvázta, elitta a bevételt is, a vagyont is. A német viszont a legújabb technológiával igyekezett dolgozni, kísérletezett. Ha nála nem volt munkalehetőség, mentek a zsidóhoz, ha ott sem, a szerbhez. Ha nagyon muszáj volt, akkor maradt a magyarnak a magyar. Mégis, a magyarokban megmaradt a rebellió iránti hajlam. A közhiedelem úgy tartja, de a protestánsok (reformátusok) önképének is szerves része, hogy a délvidéki református magyar nyakas, kossuthista, lázad az igazságtalanság ellen, megy a saját feje után. Eleve nem jobbágy, amire még kitérek. A maga ura, mert van földje.

Ha a vajdasági magyarok története valamiképp leírható lenne, azt inkább a földkérdés, semmint a magyarkérdés mentén tehetnénk meg. Kívülröl nézve persze beszélhetünk egy csoportról, amire azt mondjuk: ők a vajdasági magyarok, ilyenek és ilyenek, ezt és ezt gondolják magukról, vagy ezt és ezt írták magukról íróik, falukutatóik, riportereik, értelmiségieik. A rögvalóság azonban mindig röghöz kötött volt, a szó szoros értelmében. Nem véletlen, hogy az ottani magyar plebsz körében két politikai mozgalom vált népszerüvé a II. világháború elött. Azok, amelyek földet kínáltak a föld nélkülieknek. Az egyik a kommunista mozgalom volt - a II. világháború legelején a vajdasági magyar kommunista mozgalmat szinte teljesen lefejezte a bevonuló Horthy-hatalom, aminek az lett az ára, hogy a háború után, a titói Jugoszláviában alig akadt magyar kommunista, aki legalább részben kiállhatott volna az amúgy is pauperizálódott, periférián élő magyarság érdekeiért. A másik a nyilas mozgalom, mely különösen a Tisza mentén volt népszerü. Nehéz kiszámolni, de egyes ada- 
tok arra utalnak, hogy Zentán tartották a magyarságcsúcsot, már ami a nyilas párttagok számát/arányát illeti. De nem annyira a faji kérdés, az ordas nyilas eszmék érdekelték őket. Még az antiszemitizmus sem, bár Zentáról kb. 1500-an váltak a holokauszt áldozatává, a komplett ortodox közösség is. Vagyonukat a magyarok hordták szét, de a deportálás elsősorban a központi hatalom müve volt, nem a helyieké. Ám a nyilas pártnak is kb. ennyi, tehát 1500 tagja volt, ez számításaim szerint azt jelenti, hogy minden második felnőtt férfi érintett volt. De miért is? Mert a nyilasok ígértek nekik földet, más senki, a kommunistákon kívül (noha 1941-ben a visszacsatoláskor ebben reménykedtek a nincstelenek is, ehhez képest mehettek a Don-kanyarba).

A földkérdést nem a titói rendszer oldotta meg, pontosabban megoldotta az idők szelleme: az iparosítás, majd a vendégmunkáskodás nyugaton. Innentől kezdve a vajdasági magyar megint más szellemiséget szívhat magába: egyrészt látja a nyugati mintát, másrészt látja magyar testvéreit a vasfüggönyön túl, akik szegényebbek nála, s kevésbé szabadok, hisz nem utazhatnak kedvük szerint. Budapestet pedig nem érdekli a határon túliak sorsa, a helyi értelmiség, Újvidék és Szabadka, amire ösztönös reakció a Belgrád, illetve a délszláv térség felé fordulás. Jöhet a Balkánról a legjobb, ami ott kapható. Nincsenek már a németek, nincsenek a zsidók, jöhet a csevap.

Vajdasági magyarból - akik otthon élnek vagy valahol nyugaton, illetve Magyarországon, plusz azok a leszármazottaik, akikben maradt/lett valaminő vajdmagy tudat - lehet vagy négyszázezer, max. háromszázezer, ami a világ kb. 12 milliós magyarságának 2-3 százaléka. De müködhet-e feléjük a csoportizmus (a groupism)? Magyarán: felismerhetö-e egy vajdasági magyar? Talán a beszédéről igen, a nyelvjárás, a nyelvhasználat, a szerb jövevényszavak alapján stb. De habitusában? Eltanult-e valami más társadalmi gyakorlatot, akár a szerb többségtől újabban, akár a már említett korábbi hatások révén, akár emigrációban?

Igen is, meg nem is. A 90-es években a túlélés záloga volt, hogy a szerbekkel együtt csempésszen, pénzt váltson. Dolgozni úgysem volt értelme. De megtanulta a magyar azt is, hogy külföldön érdemes dolgozni. A szerb nemzetkarakterológia egyik legismertebb toposza az, amit 1989 táján mondott Slobodan Milošević: ha dolgozni nem is tudunk, háborúzni igen. A vajdasági magyarság nemet mondott ugyan a háborúzásra, de a munkára nem tudott otthon igazából igent mondani. Aki pedig külföldre távozott, büszkén vallja azt, amit a szerbektől vett át: hogy kinn bizony megbecsülik őket, mert oly jó munkások. Ehhez jön még az az önáltató mítosz, hogy a szerbiai munkaerő képzett, már csak azért is keresett nyugaton. Ami így nettó hazugság, a magyarok esetében pedig hozzá kell tenni, hogy már a hatvanas évektől feleannyi felsőfokú hallgató, majd végzettségű volt a magyarok közt, mint a többségi szerbeknél. Kevesebb közöttük az analfabéta és a minden iskolai végzettség nélküli, mint a többségben, de a középiskolát végzettek tömege legfeljebb a végzés időpontjában kezdhetett magával valamit a szakmájában. Mert azok többségét értelmetlenné tette a gazdasági válság, illetve a szakismeretek fejlődése.

A munkához való viszony, a tisztességesen elvégzett munka, a dolgosság, a szorgalom ugyanakkor igen meghatározónak tünik az identitásképzés során. Talán fontosabbnak is, mint a nemzeti identitás, hisz két nemzet peremén, a kettő közé mintegy beszorulva, folyamatosan új túlélési stratégiákat kell kidolgozni. Ha odahaza nem lehet, úgy a lábukkal szavaznak, akár ma a többszázezer magyarországi, kárpátaljai vagy erdélyi (fiatalabb) magyar. De innentől kezdve érdekes a kérdés: hová tegyük hát azt a kb. 2,5 százaléknyi vajdasági magyart? Bele a nagy magyar vájdlingba, vagy inkább a kisebb csetreszek valamelyikébe, 
mint amilyen a nyugati diaszpóráé? És ott, kinn, ki a magyar? Ki a hangadó? Londonban biztosan nem a vajdasági magyarok, hisz ők inkább a már korábban bejáratott németországi, ausztriai és svájci utat járják, s egymást viszik ki. Lassan könnyebb Bécsben havert találnom sörözéshez, mintsem a szülöfalumban. Az pedig ismét egy újabb, megnyitható fájl lenne, hogy köztük mégis miért tünik oly soknak a nagymagyar, a jobbikos, aki virtuálisan mintha Magyarországon élne, az ország politikai életét követi, noha azon legfeljebb csak átutazik, más nemigen köti hozzá. Politikailag tehát magyar magyarrá válik, miközben mindennapjai Bécshez kötik - bár németül nemigen tanul meg, hisz helyiekkel alig érintkezik, fönöke, munkatársai is honfitársai, pontosabban szülöföldjéről jöttek -, eközben ácsingózik haza, honvágya van, hiányzik neki a csevap...

Még két dologról szeretnék szólni, az egyik a látlak, tudom, hogy ki vagy kérdése, a másik meg a jobbágyságé, bár a kettő összekapcsolódik.

Nemrégiben Vajda Mihály önéletrajzát olvastam, és a következő rész tűnt fel. Ti. Vajda lakásán szabadegyetemet tartottak, s Bibó írását, a Zsidókérdés Magyarországon 1944 után címü tanulmányát dolgozták fel: „És akkor egy vicces pillanatomban azt mondtam, hogy hát igen, mi itten, valamennyien, kivéve téged, Éva, zsidók vagyunk. Néztek rám csodálkozva. Mi? Ezt te meg honnan tudod? Hát rátok néztem, meg hallottalak titeket beszélni. És honnan tudod, hogy Éva nem zsidó? Hát mit tudom én, honnan tudom, de tudom, hogy nem zsidó. Mert tényleg így van - mondta az egyikük. Hát mondom én, hogy tényleg így van. (...) Egyfajta attitűd, amiről én többnyire felismerem a zsidókat; azt hiszem, ennek az attitűdnek a döntő eleme az, hogy mindig van benne egy ironikus visszafogottság a saját álláspontot illetően is, hogy jó, jó, de azért egészen biztos nem vagyok benne” (Vajda 2017: 242). Majd elemzés következik arról, hogy az Orbán-féle fideszesek a több százezernyi lélekszámú paraszti csoportból származnak, ezért zárták ki végül a budapesti zsidó értelmiségből jövő társaságot a pártból, vagy távoztak azok a parasztivadékok nyomására.

Mindebben tehát lehet, van is igazság. Úgy a Fidesz vezetőségének a szociogenezisét illetően, mint abban, hogy Vajda úgymond tényleg felismerte, ki zsidó és ki nem. Megvallom azonban, ez a képesség nekem kissé gyanús, és nem is szimpatikus. 1992-ben kerültem Budapestre, addig én zsidókérdésről nem hallottam, a holokausztról sem igen, vagy ilyesmire nem emlékszem - az általános és középiskolában leginkább a jugoszláv partizánokról tanultunk. Az egyetemen aztán kiderült, hogy zsidók nem csak a Bibliában vagy a II. világháborúról szóló történetekben léteznek, hanem a valóságban is, diáktársaim, tanáraim között bár korántsem voltak vallásosak. Ma már persze talán felismerem valakiben a zsidót (jártam Izraelben, a hadseregükben is), de az, amiről Vajda beszél - ti. hogy a zsidókban van egy ironikus visszafogottság a saját álláspontot illetően -, az ordítóan általánosító baromság, mert mondjuk minden humoros, önironikus, szellemes zsidóra (vagy zsidó származásúra), akit ismerek (vagy olvastam, láttam filmjét stb.), jut egy hihetetlenül bigott, karót nyelt zsidó is, vagy mit tudom én milyen ember. Vajda zsidófelismerő képessége tehát aligha szimpatikus, mert ugyanúgy csoportista, mint a nacionalistáké, akik tagadják ama lehetőségünket, hogy mi magunk eltávolodhatunk a csoporttól (saját korábbi csoportunktól akár), s eközben kiépülő, többes identitásunk a kultúrnemzet-felfogás szigorú hívőinek szemében egyből gyanússá válik.

Ez az a rémes tulajdonság, ami a vajdasági magyarok egy részénél is megjelenik: a különlegességtudat, hogy mi mások vagyunk, s bizony, jobbak is. Mert a Balkán, a jugó idők hatására, de különben is, mi lazábbak vagyunk, tudunk élni, bennünk Apolló mellett ott az 
igazi dionüszoszi, dolgozni is tudunk, de élvezni is az életet. Szinte még egy Kusturica-filmbe is beleillünk. A magyarok viszont, ugye, ők meg olyanok, amilyenek. Bigottak, elmaradottak, konzervatívak, népiesek, vallásosak. Különösen az erdélyiek meg a kárpátaljaiak... Az effajta attitüdnek is lehet igazságmagja. Így a 2015 végén a Kárpát-medencei határon túli magyar X, Y generáció (15-29 évesek) körében végzett ifjúságkutatás (Papp Z. 2017) eredményei alapján a vajdasági magyar fiatalok tényleg lazábbak, különösen a kárpátaljaiakhoz, de sokban az erdélyiekhez képest is: sokkal inkább füveznek, előbb néznek a pohár aljára, cigiznek, ahogy a csövön kifér. A vallás, a (megtartó) egyház egyáltalán nem érdekli őket, általában liberálisabbak az élet kérdéseiben, a legkevésbé nackósok, fontosak számukra a nemzeti értékek, ők azok, akik a többségi rádióadókat is hallgatják (igaz, főleg zeneiket). A terepkutatás során azonban ugyanazt éreztem, mint Vajda szavai kapcsán, azaz mint a zsidók kapcsán: igen, akadnak köztük szellemesek, lazák, jófejek - meg nagy seggfejek is. És amióta olvashatom szükebb hazám képviselöit mint Facebook-kommentelöket, az az érzésem, mintha egyre több bunkó akadna köztük. Korábban, a 2000-es évekig mégis elsősorban a nyomtatott sajtóban olvashattam kis hazám fiait, oly liberális folyóiratokban, mint a legendás Új Symposion vagy a Magyar Szó. Mely utóbbi ma már inkább a Magyar Időkhöz hasonlít.

Természetesen, aki az utóbbi évtizedekben a Balkánon, a volt Jugoszlávia területén cseperedett fel, élt vagy él, aligha lehet mentes a nacionalizmusok hatásától, azon belül a túlfütött nemzetkarakterológiától. Amennyire idegenkedik tölük, öntudatlanul is oly sokat vesz át belőlük, s mintegy hobbijává válik a nemzeteszmével és a nemzetkarakterológiával való foglalkozás. Hogy tényleg úgy állnak a dolgok, ahogyan? Jómagam is kedvvel forgatom Vladimir Dvornikovićnak, kora nagy etnológusának 1939-ben megjelent Karakterologija Jugoslovena című tudós munkáját, amelyet azóta természetesen megevett a tudományos módszertan és fejlődés, mégis alapmű $A$ délszlávok jellemrajza címü hatalmas opus, amelyben például egy kanadai vicc kapcsán értelmezi, miért is oly lusták a montenegróiak. Ő egyébként tudományos alapon munkálkodott azon, hogy a horvátokat, szerbeket, szlovénokat stb. egy nemzetté, a jugoszlávvá kell formálni - s nem politikain. Ez azonban még az akkori, projugoszláv hatalomnak is sok lehetett, és 1926-ban, 38 éves korában nyugdíjazták (aztán 1938-ban még egyszer, véglegesen). Szóval, e vidékeken nem ártatlan dolog a nemzetkarakterológia. De nincs új a nap alatt, és minden toposz visszaköszön, mintha a nemzetek egymástól vennék, egymásnak adnák el a nemzetkarakterológiai közhelyeket.

$S$ ha már a szerbekről és magyarokról van szó, íme egy újabb példa. A szerb munkaügyi miniszter 2018-ban március 8. alkalmából úgy nyilatkozott, hogy a (szerb) „nő nem tud tisztelni, hanem szeretni, a nőnek nem szükséges, hogy tiszteljék, hanem csak az, hogy szeressék (...) Minden nő a gazdagokat szereti, mert a nő mindig szegény. Az okosoktól félnek... A nő mindig lefekszik az erősebb előtt, és nem a szebb vagy az okosabb, sem nem a jobb vagy a kedvesebb előtt..." Az igaz, hogy szavai bombaként robbantak, bocsánatot is kért, de semmi következménye nem lett, lemondania sem kellett. Szavai pedig nem sokban különböznek attól, amit ma Magyarországon hallhatunk az uralkodó kaszt képviselőitől a nőkről - az áporodott macsóság szaga terjeng a Balkánon is, Közép-Európában is.

S ezt a jelenséget, aminek a nők lenézése, „konyhában a helye” típusú helyretevése csak egyik eleme, többen már a jobbágymentalitás tovább-, avagy újraéledéseként írják le. Ismét csak Vajda Mihályt idézném: „Hát a demokratikus készségek szempontjából semmi sem változott, de egyvalami maradt. Ez a több százezres, milliós jobbágy-mentalitású tömeg. A többség jobbágy-mentalitású. Mindent elfogad, mert éppen ez a szabály. Ez a szabály, 
és a szabályokat be kell tartani, punktum. A szabályt persze többnyire muszáj betartani, de lehet hozzá distanciált a viszonyunk. Senkinek sincs. Ott ül, akárhol, és azonos a szabálylyal, ő a szabály, szabályként viselkedik. (...) Az értelmiség többnyire nem érti, nem akarja érteni, hogy egy olyan jobbágy-mentalitású tömeggel áll szemben, amelynek a mentalitása másutt sem változott egyik napról a másikra, iszonyatosan hosszú folyamat ez" (Vajda 2017: 236-237). S hasonlóképpen beszélt Vajdával egy időben Spiró György is 2017 végén: „Úgy látom, hogy lassan az egész világ magyarrá válik. A (...) modern világban sokfelé létező archaikus struktúrákról [írok], amiket lehet törzsinek vagy feudálisnak nevezni, mindenesetre ellentétesek a felvilágosodás eszméivel. Magyarországon nem új az a mentalitás, hogy nem munkával, hanem rablással lehet vagyont szerezni; gyakorlat volt a Horthy-korszakban, a nyilasok idején és a háború után egyaránt. Ahogy az előjogok rendszere is szinte folyamatosan müködött, a dzsentrivilágban és a szocializmusban is, csak a kiváltságosok cserélődtek. (...) Létrejött egy félfeudális államkapitalizmus, amilyen egyébként a világ számos országában hasonlóan müködik. (...) Mindenhol, ahol a polgári forradalom nem tudta teljesen megsemmisíteni a feudális struktúrákat, ahol tovább él a jobbágymentalitás. Évszázados tapasztalat az ilyen térségekben, hogy csak önfeladással, hajbókolással lehet túlélni, és az állam képviselőihez kell dörgölőzni” (Spiró 2017).

Vajda és Spiró mondatai természetesen esszészerüek, publicisztikusak, azaz kemények és sarkosak. „Van benne valami”, de gondolatilag inkább, illetve épp azért lehetnek megtermékenyítőek, mert részben cáfolhatók. Például éppen a vajdasági magyarokkal példálódzva, de akár a magyarság más csoportjaival is. Ugyanis a vajdasági magyarok kisebbségben, az elmúlt száz évben számtalanszor vetették le a jobbágymentalitást. Ami, úgymond, a szerb választókra is oly igaz, legalábbis ez is egy közismert toposz. Hogy egyet mondjak: a kilencvenes évek legnagyobb szerb ellenzéki vezetője, Vuk Drašković többször felidézte azt az anekdotát, hogy a választási kampány során megkérdezte a szerb parasztot, miért is nem szavaz rájuk, ha az ő mozgalmával ért egyet. „Tudod, fiam - mondta az öreg -, majd ha ti lesztek hatalmon, akkor rátok szavazok.” Vagyis a szerb paraszt, a szerb „jobbágy” is a mindenkori hatalomhoz dörgölődzik. Ám mégis, kisebbségi sorsba kerülvén a magyarok többsége általában miért nem dörgölödzött a hatalomhoz, miért alakította meg saját etnikai pártjait, már amikor ez lehetséges volt, miért akadt köztük oly sok ellenzéki? A vajdasági magyarok miért mondtak nemet, azaz mertek nemet mondani Slobodan Milošević háborús politikájára?

$S$ hogyan is van ez a jobbágykérdés, ha úgy a szerb, mint a magyar nemzet, nép önképének szerves része a szabadságszeretet, a harc - még ha végül el is véreznek a csatatéren? Ha egy részük lázadó, akkor mégis, a jobbágymentalitás miért oly általános? Nem tudom - azt persze látjuk, hogy sokan a hatalomhoz dörgölődznek, gyakran mert más lehetőségük nincs is.

És ott a lázadás, a kivonulás legtömegesebb formája: az elvándorlás. Ha 100-120 év során milliókra tehető már azok száma, akik emigráltak a magyarok lakta vidékekről (tudjuk jól, nemcsak magyarok, köztük aránytalanul sok szlovák is), enyhén szólva nehéz mit kezdeni a jobbágyozással, mert a jobbágy mindig röghöz kötött volt, aki nem hagyhatta el az adott területet sem, robotolhatott élete végéig a földesúrnak. De ahogy felszabadultak, tömegesen fogták koldusbotjukat. A jobbágyozás tehát lehetséges, de mégsem elégséges magyarázat arra, mi történt, mi történik a magyarokkal, habitusukkal, társadalmi gyakorlataikkal. Hisz nemcsak azok habitusa változik meg egyik napról a másikra, akik nyugatra emigrálva vállalnak munkát, változnak meg szinte rögtön és válnak akár sikeressé is. Különösen érdekesnek tünik e kérdés a határon túli magyarok esetében, akiknek a túlélés érdekében még szofisztikáltabb 
technikákkal kell élniük. A vajdasági magyarok esetében pedig nemcsak arról lehet beszélni, hogy kisebbségbe kerültek, hanem arról is, ahogyan arra utaltunk, hogy a hatvanas évektől kezdődően nem kis számuk vált vendégmunkássá, kétlakivá, vagy tért akár vissza onnan kisebb-nagyobb tőkével, és vett földet, mezőgazdasági eszközöket, lett kisiparos (a szocializmusban akár húsz embert is foglalkoztathatott egy vállalkozó, bár ez elég ritka volt, inkább maximum ötöt). Minderről nem kívánok bővebben írni, de utalnék rá, hogy úgy a személyes tapasztalatok, mint a látható példák bizonyára kihatottak a gyakorlatra, de legalábbis az elképzelésekre, tervekre, arra, hogy a magyarok fejében is megforduljon az, hogy van más, járhatóbb út is, mint a látszólagos jólétet és biztonságot nyújtó jugó szocializmus.

De számtalan más hasonlóságot is megemlíthetnék a szerbek és magyarok között. Az egyik az önkép ama része, miszerint a mi népünk hordozza magában az igazi európai értékeket, védi meg a kereszténységet az iszlámtól. Hogy ez a nép ősi, a legősibb, ahogyan a nyelve is. Krisztus is magyarul (szerbül) beszélt. És hogy Magyarország (Szerbia) az utolsó bástya Európában, amelynek kultúráját meg kell őrizni, mert ez a legigazibb kultúra, amelyet nem vert tönkre a civilizáció.

De hát ez is mind ismerős szöveg. És nagyon nem eredeti. Mert a német romantikusok is hasonló zagyvaságokat tudtak mondani, bár kétségtelenül sokkal jobban becsomagolva. Novalis még látta, hogy: „Miközben az alantasnak magasztos értelmet, a megszokottnak titokzatos küllemet, az ismertnek az ismeretlenség méltóságát, a végesnek a végtelen látszatát kölcsönzöm, romantizálom azt.” Az öreg Goethe is hozzáfüzte, hogy szép, szép ez az egész, de minden beteg, ami romantikus... Ám 1914-ben sokan vallották azt nem mással, mint Thomas Mann-nal együtt (később ugyan megbánva), hogy Németország romantikus kultúráját meg kell védeni a nyugati civilizációval szemben. Mondták ezt a nyugati civilizáció egyik középpontjában, Németországban... De aztán jött a nemzetiszocializmus, mint pervertált racionalizmus, lezüllesztették az észszerüséget, s belerohantak a késbe, jött Németország, a németség mélypontja...

Ehhez képest hol áll a magyarság, ki a magyar? Nem tudom, de azt meg merem kockáztatni, hogy vajdasági része két-három évtized múlva egypár tízezres, falun, legfeljebb kisvárosokban élő, elöregedett, szociálisan és minden más értelemben lemaradt, nyelvét, kultúráját még éppen őrző közösség lesz. De ahogyan azt a kilencvenes évek elején, első demográfiai órámon Cseh-Szombathy Lászlótól, a szakma doyenjétől tanultam: nem az a fontos, hogy egy közösségnek hány tagja van, hanem hogy azok hogyan élnek. Nos, úgy tünik, ezt a leckét a magyarság sem tanulta meg, azóta sem.

\section{Hivatkozott irodalom}

Badis Róbert (2008): A vajdasági magyarság identitásstratégiái. In Bennünk élő múltjaink. Papp Richárd és Szarka László (szerk.). Zenta: Vajdasági Magyar Művelődési Intézet, 319-327.

Gábrity Molnár Irén (2008): A délvidéki identitástudat nyománban. In Bennünk élő múltjaink. Papp Richárd és Szarka László (szerk.). Zenta: Vajdasági Magyar Művelődési Intézet, 307-318.

Gábrity Molnár Irén és T. Mirnics Zsuzsanna (2002): Vajdaság. In Mozaik 2001 Gyorsjelentés. Magyar fiatalok a Kárpát-medencében. Szabó Andrea et al. (szerk.). Budapest: Nemzeti Ifjúságkutató Intézet, 239-288.

Losoncz Alpár (2017): Az autonómia/heteronómia horizontja. In Ki vagy te, vajdasági magyar? Losoncz Márk (szerk.). Újvidék: Forum, 85-123.

Papp Z. Attila (szerk.): Változó kisebbség. Kárpát-medencei magyar fiatalok. Budapest: MTA TK KI - MCC Tihanyi Alapítvány. 
Spiró György: „Tovább él a jobbágymentalitás.” Interjú. HVG (2017. január 6.). Interneten: http://hvg. hu/kultura/201749_spiro_gyorgy_diktaturarol_elmeszesedesrol_feudalizmusrol_ttovabb_el_a_ jobbagymentalitas (letöltve: 2018. április 05.).

Vajda Mihály (2017): Szög a zsákból. Budapest: Magvető.

Zahra, Tara (2017 [2010]): Képzelt nemközösségek: nemzeti közömbösség, mint elemzési kategória. Regio 25(2): 5-42. Interneten: http://regio.tk.mta.hu/index.php/regio/article/view/159 (letöltve: 2018. április 05.). 